\title{
Supply chain integration within global manufacturing networks: a contingency flow-based view
}

\author{
Ruggero Golini, (Department of Management, Information and Production \\ Engineering, Università degli Studi di Bergamo, Bergamo, Italy) \\ Federico Caniato, (School of Management, Politecnico di Milano, Milan, Italy) \\ Matteo Kalchschmidt, (Department of Management, Information and Production \\ Engineering, Università degli Studi di Bergamo, Bergamo, Italy)
}

Citation: Ruggero Golini, Federico Caniato, Matteo Kalchschmidt, (2017) "Supply chain integration within global manufacturing networks: a contingency flow-based view", Journal of Manufacturing Technology Management, Vol. 28 Issue: 3, pp.334352, doi: 10.1108/JMTM-11-2015-0100

DOI: http://dx.doi.org/10.1108/JMTM-11-2015-0100

\begin{abstract}
Purpose. The paper aims to analyse how the role of the plant in a manufacturing network affects the configuration of the flows of goods among plants, suppliers and customers and how this configuration, in turn, affects the extent of adoption and effectiveness of supply chain (SC) integration.
\end{abstract}

Methodology. Three research questions are developed at the plant level and then investigated through Cluster analysis, MANOVA and regression, using data from an international survey (IMSS 6) featuring 364 plants, from 18 countries, which are part of an intra-company manufacturing network.

Findings. Five configurations of flows of goods emerge from the analysis. These configurations appear to be related to the role of the plant in the network and partly to the effectiveness of SC integration practices, but not to their extent of adoption.

Research limitations. Research limitations include the focus on specific industries (assembly industries) and limited size of the clusters, which did not allow for a deep investigation of each single cluster.

Originality/value. The paper creates a bridge between two literature streams (manufacturing networks and SC management) by means of an innovative flow-based perspective that can help researchers and practitioners to disentangle the two interwoven perspectives.

Keywords: Global Manufacturing Networks, Supply Chain Management, IMSS 


\section{Introduction}

The design of global manufacturing networks is going through radical changes. For multinational companies, the evolution from streamlined supply chains to value and knowledge networks (Berghman et al., 2012) makes the decisions related to the location of production facilities and how to control and coordinate the production network increasingly related to the structure of the supply chain (SC) in which the company is embedded (Brennan et al., 2015). In other words, the internal and the external network perspectives are converging and calling for more research able to merge them in comprehensive frameworks.

Past research on multi-plant organizations focused mainly on localization decisions in designing a manufacturing network (MN) (Shi and Gregory, 1998), with the main driving variable being cost (Schmenner, 1979). In the last years, however, other contributions have extended the set of variables that can be considered to characterize plants within multinational networks such as localization reasons (i.e., low cost resources, proximity to market, access to skills and technology), autonomy and responsibility of the plant, contribution to and integration in the network (Feldmann and Olhager, 2013; Ferdows, 1997; Vereecke and Van Dierdonck, 2002).

Starting from the seminal work of Ferdows (1997), previous studies demonstrated that plants have different roles, mainly as a combination of their localization advantage and competences (Cheng et al., 2011; Feldmann and Olhager, 2013; Ferdows, 1997; Vereecke and Van Dierdonck, 2002). According to these studies, the role of one plant can range from just being a productive unit to contribute to process and product development for the whole network, thus becoming a centre of excellence. In between, plants can have responsibility on SC activities, namely purchasing and distribution. Recently, other roles have been identified, for instance, the plants in low cost countries that serve as purchasing outposts for the rest of the group (Sartor et al., 2015). Feldmann and Olhager (2013) found that a relationship exists between the role of the plant (based on the competences) and the performance of the plant. However, the implications of the different roles based also on configuration and coordination aspects of the network at the operational level and in particular considering also how the SC is managed remain underexplored.

Still, it is reasonable to assume that plants that are independent from the rest of the network and with higher responsibility will approach SC management differently from those that are highly dependent from the network an with a more executional role. In order to address this gap, the aim of this paper is to analyse the relationship between the role of the plant and its level of integration with suppliers and customers. Supply chain (SC) integration is in fact considered one of the key variables in managing the SC and one of the best practices to achieve efficiency and effectiveness (Danese and Romano, 2011; Flynn et al., 2010), especially in a global SC context (Caniato et al., 2013). However, the relevant number of variables that characterize the role of the plant and the fact that they are typically governed at the corporate level makes it difficult to establish causal relationships between them and SC integration at the plant level. For this reason, we assess the role of the plant by means of the flows of goods that are exchanged as inputs or outputs with the other plants in the network (in contrast to the flows that are exchanged with external SC partners). In fact, as we will explain in the literature review, we deem that the role of the plant is connected to such flows and these in turn are related to how the SC is managed. Our results also support this approach. In particular, by means of the data gathered within the sixth edition of the International Manufacturing Strategy Survey (IMSS 6), we establish how the multidimensional concept of the role of the plant is related to different configurations of flows of goods 
within and outside the network. Moreover, these flows appear to be related to the effectiveness of SC integration on operational performance, rather than to the extent of adoption of SC integration practices.

The paper is therefore organized as follows: in section 2 we provide an overview of the literature on the topic and develop our research framework and questions; in section 3 we present the research methodology; in section 4 the results are illustrated; section 5 discusses the results and finally in section 6 the conclusions are drawn.

\section{Literature review, research framework and questions}

\subsection{Supply chain integration in manufacturing networks}

According to their recent literature review, Alfalla-Luque et al. (2013) find three dimensions of SC integration: 1) information integration, coordination; 2) resource sharing; 3) organizational relationship linkage. Each one can take place with customers, other functions within the company or with suppliers. In this paper, we focus on integration with suppliers and customers. Several studies have highlighted the importance of SC integration to achieve a competitive advantage and to improve operational performance (Flynn et al., 2010; Frohlich and Westbrook, 2001; Vickery et al., 2003; Zhao et al., 2008) as well as its relevance in preventing issues such as the well-known bullwhip effect (Lee et al., 1997). As for other best practices (Hayes and Wheelwright, 1984), it is fundamental to align the extent and scope of SC practices to the firm's external and internal context (Flynn et al., 2010). In fact, according to the contingency theory, the impact of best practices depends on the environment in which the company operates (Ketokivi and Schroeder, 2004; Powell, 1995; Sousa and Voss, 2001; Sousa and Voss, 2008). As a consequence, the impact of SC integration has been recently studied under the effect of different contingent variables. For instance, Wiengarten et al. (2014) found that the logistical characteristics of a country affect the effectiveness of SC programs. Wong et al. (2011) found that environmental uncertainty plays a moderating role between SC integration and performance. Caniato et al. (2013) show how the global SC configurations moderate the relationship between SC improvement programs and operational performance. Danese et al. (2013) highlight the role of having an international supplier network in the relationship between supply chain integration and responsiveness. Finally, Gimenez et al. (2012) studied the moderating effect of supply complexity on the relationship between supply chain integration and performance.

However, the majority of studies on SC integration used the firm as the unit of analysis, disregarding the potential effect of the intra-company manufacturing network configuration. In particular, Rudberg and Olhager (2003) pointed out that the two perspectives of manufacturing network $(\mathrm{MN})$ and supply chain $(\mathrm{SC})$ have been very seldom integrated and we deem that this situation still endures. The only situation in which the two perspectives (MN and SC) have been integrated can be found in the the concept of embeddedness of a subsidiary in the internal and external networks (e.g., Meyer et al., 2011). Embeddedness is mainly related to the knowledge flows that can foster innovation and competitive advantage (Achcaoucaou et al., 2014; Najafi-Tavani et al., 2014). In this interexchange of knowledge flows, the plant can be a giver and/or a receiver (Gupta and Govindarajan, 1991; Gupta and Govindarajan, 2000; Monteiro et al., 2007). 
However, in the operations management field, different configurations of a $\mathrm{MN}$ have been analysed (e.g., market vs. process orientation; multinational vs. global; role of the plants) (e.g., Ferdows, 1997; Shi and Gregory, 1998), but, even in the most recent reviews (e.g., Cheng et al., 2015), the connection with SC management remains underexplored.

As a consequence, starting from the well-established relationship between SC integration and operational performance, we aim at investigating whether the configuration of the MN network affects the extent of adoption and effectiveness of SC integration.

\subsection{Flow of goods and role of the plant}

Following a logic similar to the knowledge flows (Gupta and Govindarajan, 2000; Vereecke et al., 2006), we focused on the actual flows of goods entering and exiting from one plant, which should provide an outlook of the MN configuration from an Operations Management perspective.

With reference to Figure 1 and in relation to a specific plant in the network, we define:

1. Vertical inflows: flows of goods from external suppliers.

2. Vertical outflows: flows of goods to external customers.

3. Horizontal inflows: flows of goods from other plants of the network.

4. Horizontal outflows: flows of goods to other plants of the network.

\section{TAKE IN FIGURE 1}

As the percentage of vertical inflows (outflows) is equal to $100 \%$ minus the percentage of horizontal inflows (outflows), in the reminder of the paper we will consider only the horizontal inflows (outflows) in order to identify different configuration of flows. This flow-based perspective is instrumental to reconcile the MN with the SC dimension. As it can be seen in our research framework (Figure 2), we use the flow-based taxonomy to connect the $\mathrm{MN}$ dimension (i.e., the plant role, on the left) with the SC dimension (i.e., SC integration and performance, on the right). In particular, we claim that the plant role, which is decided at the headquarters level, affects the configuration of flows that can be a relevant contingency to explain differences in the adoption and effectiveness of SC integration. In this way, we aim to contribute to the literature on $\mathrm{MN}$ by showing the impact of network configuration decisions on the flow of goods. Moreover, we aim to contribute to the SC integration literature, by adding a new relevant contingency. In the next paragraphs, the items considered in each box of the framework are further explained as well as the relationships among the variables.

\section{TAKE IN FIGURE 2}

Beside networks in which horizontal or vertical flows dominate, it is possible to find also the case in which the horizontal and vertical dimensions coexist, thus generating complex mixed situations (Rudberg and Olhager, 2003). 
As a consequence, the first objective of this paper is to investigate the relationship between the MN layer (i.e., the role of the plant) and the flow-based taxonomy. With this purpose in mind, we reviewed the literature seeking for all the factors that can characterize the role of a plant and the flows of goods exchanged. Since Ferdows (1997) the literature on the role of the plant has traditionally focused on two characteristics: localization advantage and site competence. According to Feldmann and Olhager (2013), the most cited localization advantage by the relevant literature is proximity to market. This is in line also with the international business literature that separates networks in which the subsidiaries have a local geographical scope versus those with a global scope (Schmenner, 1982). As a consequence, the first variable we considered is "market scope", which is related to the market/geographic area served by the individual plant (Vereecke and Van Dierdonck, 2002). If the plant serves a local market, usually with a tailored product, it can be seen as the local outpost of the manufacturing network.

Next, we considered the other two classical localization advantages (Maritan et al., 2004; Meijboom and Vos, 2004):

- Low cost advantage: the plant role is to leverage on low cost local inputs (labour, materials, etc.);

- Skill and knowledge advantage: the plant role is to leverage on local presence of high skilled workers, expert suppliers or research centres.

As already mentioned, the level of responsibility (or site competences) is the other classical factor considered in the literature and included in our study. The level of responsibility refers to the capabilities that are within the plant and that, according to Ferdows (1997), range from "assume responsibility for production" (the least advanced) to "become global hub for product or process knowledge" (the most advanced).

However, other factors can be considered when characterizing the role of a plant: we considered also the "production scope", which is related to the extent to which the plant performs the entire production process. Usually, plants with a small scope are process specialist in a fragmented MN or SC (Hanson et al., 2005) .

Furthermore, we considered the level of "control", related to the decisional autonomy of the plant (e.g., McDonald et al., 2008; O'Donnell, 2000; Young and Tavares, 2004).

Finally, we considered the extent of integration of the manufacturing plant with other plants of the same company (Cheng et al., 2011; Meijboom and Vos, 1997) as a relevant $\mathrm{MN}$ variable characterizing one plant. The $\mathrm{MN}$ integration can include knowledge exchange; information sharing about suppliers, production or demand; innovation sharing and integration of IT systems (Cheng et al., 2011; Colotla et al., 2003; Rudberg and West, 2008; Szulanski, 1996).

All the variables mentioned above have the potential to influence the configuration of flows of one plant, even if, to the best of our knowledge, this relationship has never been systematically investigated. In conclusion, the first research question we address in the paper is:

RQ1. How are the variables that define the role of the plant (i.e., market scope, low cost advantage, skill and knowledge advantage, responsibility, production scope, control, level of $M N$ integration) related to the configuration of flows of goods of a plant?

\subsection{Flows of goods, SC integration and operational performance}

As a second objective, we want to investigate the relationship between the flows of goods and SC integration. In our paper, SC integration is defined as the integration with 
suppliers and customers thus as a best practice to improve efficiency and responsiveness (Flynn et al., 2010; Wiengarten et al., 2014).

The relationship between the role of the plant and SC integration is quite controversial. On one side, some studies show that plants that are subject to a higher degree of control and have lower levels of responsibility are usually less integrated in the SC (Andersson and Forsgren, 1996; Birkinshaw et al., 2005; Gammelgaard et al., 2012). On the other side, the high control can be related to the fact that the plant has relevant localization advantages (e.g., low costs, access to market, skills or know-how) and in this situation the plant and the network should have interest in being highly integrated in their SC in order to exploit such advantages. Because of this, we deem that looking at the flows can help to solve the problem as we expect that plants with higher degrees of vertical flows will be more interested in being integrated in the SC. As a consequence, our second research question is the following:

RQ2. How does the configuration of flows of goods of a plant affect the extent of SC integration with suppliers and customers?

Finally, since SC integration is broadly acknowledged for improving effectiveness and efficiency (Flynn et al., 2010; Wiengarten et al., 2014), research has focused on the contingent variables that can moderate such relationship. Similarly, we aim to investigate whether the configuration of flows affects the relationship between SC integration and performance. Given the lack of literature on this specific topic, it is quite difficult to formulate hypotheses. From one side, being more exposed to vertical flows should favour the effectiveness of SC integration, as it can be applied more extensively. On the other side, having exchanges within the MN can have synergetic effects, like it happens with knowledge exchanges (Gupta and Govindarajan, 1991; Gupta and Govindarajan, 2000; Monteiro et al., 2007). In conclusion, our third research question is:

RQ3. How does the configuration of flows of goods of a plant affect the effectiveness of SC integration in improving operational performance?

\section{Research methodology}

The research questions have been investigated by means of the data collected in 20132014 in the $6^{\text {th }}$ edition of the International Manufacturing Strategy Survey (IMSS 6) (www.manufacturingstrategy.net). This project, originally launched in 1992 by the London Business School and Chalmers University of Technology, studies manufacturing and supply chain strategies within the assembly industry (ISIC 25-30 classification) through a common questionnaire administered simultaneously in many countries by local research groups (Lindberg et al., 1998). The main research goal of the project is to investigate the relationships among strategic priorities, manufacturing and supply chain practices, improvement programs, performance and contingent variables.

Companies are usually selected from local databases and the operations, production or plant manager is contacted regarding the willingness to participate in the research. If the respondent agrees, the link to the online questionnaire is sent out. When necessary, a reminder is sent after a few weeks. Questionnaires that are completed are controlled for missing data, which are handled case by case, usually by contacting the company again. Finally, all data are grouped into a unique database, which is further controlled by the project coordinators (the authors of this paper) and distributed to all partners. 
The first section of the questionnaire is related to the business unit (gathering general information, such as company size, industry, production network configuration, competitive strategy and business performance), whereas the other sections refer to the plant (focusing on manufacturing strategies. practices and performance). Although the structure of the questionnaire has remained the same with every edition, some questions have been updated or removed and new questions have been added by the design team, which is composed of a pool of international researchers, to avoid researchers' country biases (Van de Vijver and Leung, 1997). From the original sample of more than 800 answers, we drew 364 usable answers from companies belonging to 18 different countries. The selection was based on the following criteria:

- Only cases belonging to a company-wide manufacturing network.

- Only companies with more than 50 employees.

- Only cases providing all the information needed for this study.

- Only countries providing at least 10 cases at the end of the selection.

Table 1 shows the distribution of the sample in terms of country, industry and size used in this study.

\section{TAKE IN TABLE 1}

Horizontal inflows were measured by a question asking the percentage of value of inputs (materials, components, sub-assemblies products) received from other plants/units in the network and double-checked asking the percentage received from external suppliers (sum must be 100\%). Horizontal outflows were measured by a similar question asking the percentage of value of outputs distributed to other plants/units in the network and double checked asking the percentage distributed to external customers (sum must be 100\%). We applied a hierarchical cluster analysis first, based on squared Euclidean distance and the Ward method, to identify the most suitable number of clusters and the cluster centroids. The analysis of the agglomeration schedule suggested five clusters. Next, the K-means clustering algorithm was used to iteratively assign each case to a cluster (Ketchen and Shook, 1996). Figure 3 and Table 2 report the results of the cluster analysis.

\section{TAKE IN FIGURE 3}

\section{TAKE IN TABLE 2}

We can notice how the majority of the plants falls in the Cluster 2 with limited horizontal exchanges. As a preliminary analysis we checked whether differences among clusters exist according to four variables (Table A1 in the Appendix): extent of the manufacturing network (national, regional or global), ISIC code, country and size. We found that the clusters are quite evenly distributed by industry and size of the company. The analysis by country shows relevant differences, but without an identifiable pattern. For instance, compared to other countries, Denmark, India, Japan, Malaysia, Romania and USA have a percentage of companies in Cluster 2 lower than the average. Finally, companies in Clusters 2, 3 and 5 seem to belong to more globalized networks, while companies in Clusters 1 and 4 are more evenly distributed.

Next, in order to investigate our research questions, we verified the association between the clusters and a set of variables characterizing the role of the plant in the network 
(RQ1), the extent of the integration with suppliers and customers (RQ2) and the effect over the performance (RQ3).

The constructs and the measures are reported in Tables A2 and A3 in the appendixes. We performed confirmatory factor analysis (CFA), which displayed sufficiently high factor loadings, composite reliability $(\mathrm{CR}>.66)$ and average variance extracted (AVE>.66) for the constructs (Table 3). Only the two items related to market scope showed a low reliability, and, in particular item MS1 (related to the geographical extent of the market served by the plant) shows the lowest factor loading. As a consequence, we dropped it for the rest of the analyses, considering only the item MS2 (related to the adaptation of the product to the local needs) to measure market scope. The constructs also pass the discriminant validity test using the Fornell and Larcker (1981) procedure, i.e. checking that the square root of average composite reliability of each construct is always larger than the correlation with the other constructs (Table 4). Overall, the model presents sufficient fit indices $\left(\chi^{2} / \mathrm{df}=1.940 ; \mathrm{NFI}=0.87\right.$; CFI $=0.93$; RMSEA $\left.=0.05\right)$ according to the suggestions provided by the literature (Byrne and Stewart, 2006; Hair et al., 1998; Sharma, 1996). Given the presence of single-item constructs in the variables characterizing the manufacturing network (i.e., market scope, production scope, low cost advantage, skill and knowledge advantage), we have also performed an exploratory factor analysis (EFA) to double check their discriminant validity (Table A4).

The constructs made of multiple items were calculated as the average of the single items.

TAKE IN TABLE 3

TAKE IN TABLE 4

\section{Results}

Table 5 reports the results concerning RQ1. We performed a MANOVA analysis that tested if significant differences existed among clusters on the plant role variables and at the same time controlling for:

- Company size (log of the number of employees): company size has been often punt in relation to higher adoption of SC integration thanks to the higher availability of resources and power to establish such mechanisms in the chain (Golini et al., 2016)

- Geographical extent of the manufacturing network (regional vs. global): global networks are more footloose thus hampering the development of SC integration (Ferdows et al., 2016)

- GNI per capita of the country: the level of development of a country can affect the adoption of SC integration practices (e.g., Wiengarten et al., 2014)

For each variable we checked whether the Levene's test was passed. Only for two variables (Market Scope and Control) it was not, so we double-checked the significance by means of a non-parametric test. Where the MANOVA indicated significant differences (i.e., Production Scope, Control, Low Cost Advantage and MN Programs) we checked the pairwise differences by means of a LSD test. The MANOVA did not 
identify significant differences for Market Scope, Responsibility and Skill and Knowledge Advantage.

\section{TAKE IN TABLE 5}

Similarly, to investigate RQ2 we performed a MANOVA analysis that tested if significant differences existed among clusters on the SC integration variables at the same time controlling for: company size (log), geographical extent of the manufacturing network (regional vs. global) and GNI per capita of the country. For each variable we checked whether the Levene's test was passed. The analysis highlighted no difference among clusters (Table 6).

\section{TAKE IN TABLE 6}

Finally, in order to test the moderation effect of the clusters on the effectiveness of SC integration practices with suppliers and customers, we performed a set of regression models. First of all, we tested the relationships without considering the clusters, which confirmed the positive association already established in the literature between performance and SC integration on both supplier and customer side (Table 7). In each model we introduced first the same control variables used before: company size $(\log )$, geographical extent of the manufacturing network (regional vs. global) and GNI per capita of the country. Next, following the standard procedure for the moderation analysis (Baron and Kenny, 1986), in each model we added the direct and interaction effect of the cluster (Table 8). The models test separately the effect of supplier and customer integration over the performance of "cost and lead time" and "quality and delivery". Not in all the cases the clusters appear to have significant moderation effects.

\section{TAKE IN TABLE 7}

\section{Discussion}

Our results identified 5 different configurations of horizontal inflows and outflows that are associated to different roles of the plant. Looking at Table 5, we can derive the following characteristics (we also propose "names" for each configuration).

Cluster 1 - Local Process Specialist. This group features high horizontal inflows and outflows, the lowest production scope and a relatively high cost advantage. In other words, the plants in this cluster receive inputs from other plants, perform a very specific production step and send the products to other plants in the network. These plants are therefore located in MNs in which the process dimension is more relevant than the market dimension. These networks are typically able to exploit local advantages and in this case cost advantage seems to be relatively important. Given their specialization but also interdependencies with other plants in the network, it makes sense that they are subject to a medium degree of control and integration with the rest of the network.

Cluster 2 - Independent Premium Servers. This group features low horizontal inflows and outflows, high production scope, low level of control and low integration. 
These plants are very independent from the rest of the network, not only in terms of inputs/outputs and organizational integration, but they have also full control of the production from end to end and are free to manage their supply chains. Even if statistically not significant, it is not surprising that they have a high degree of responsibility and lack of low cost advantage.

Cluster 3 - Market Outposts. This cluster is characterized by high horizontal inflow and low horizontal outflow, low production scope, high control by the rest of the network and reduced cost advantages. These plants basically receive the goods from the rest of the company network to sell them in a limited geographical area (they have the lowest market scope). We double checked this result with another question from the survey, finding that about $43 \%$ of their production is for domestic customers. Because of this, their decisional power and production activities are quite limited (reasonably the final assembly and customization phases). Moreover, they are located near the final markets thus low cost advantage and access to skills and knowledge is not an important localization advantage for them. Despite the dependency of the rest of the network on their sales activities, they have quite limited levels of integration in the rest of the network, probably because the main coordination mechanism is control rather than mutual adaptation with other plants.

Cluster 4 - Low cost advantage seekers. This cluster features intermediate horizontal inflows and outflows, the strongest low cost advantage, quite high control and high level of integration with the rest of the network. Plants belonging to this cluster are located in strategic areas in terms of low cost inputs and resources. In order to maximize their local advantage and contribution to the network, they have to balance the horizontal and vertical exchanges of goods. Given their strategic role in the network, they are highly integrated in the network and are subject to a quite high degree of control from the headquarters to avoid opportunistic behaviours (i.e., exploit local advantages without sharing the benefits with the rest of the network). A good example of this kind of plants are the sourcing outposts, i.e. plants established in strategic areas, like China, that not only serve an important local market but can also scout for local suppliers in order to serve themselves and the rest of the network with low cost inputs.

Cluster 5 - Sourcing hubs. This cluster is characterized by low horizontal inflows and high horizontal outflows, therefore consists of plants that source from outside the network but then distribute their own products mostly to other plants horizontal to the network. This configuration is associated with the lowest level of cost advantage, the highest level of skill and knowledge advantage, the most international market scope and the lowest level of responsibility. Therefore, these plants are located mainly to access high-value resources both inside and outside the firm, disregarding cost, for the benefit of the whole network, with a limited autonomy and a rather low production scope.

Moving to our second research question, Table 6 shows no significant differences among clusters in terms of SC integration with both suppliers and customers. In general, supplier and customer integration are relatively high in our sample, even for the Local Process Specialists (Cluster 1), which, having little vertical flows, were expected to have lower integration. This result provides evidence that the integration in the SC seems to follow different logics compared to $\mathrm{MN}$ integration that instead differs among clusters (Table 5). While MN integration is varied according to specific conditions related to the role of the plant, SC integration is considered important for each type of 
plant, even those with reduced vertical flows. As matter of fact, even the Local Process Specialists (Cluster 1) have a residual $15-20 \%$ of their flows exchanged with suppliers and customers (Table 1). Our results suggest that in this small percentage there are strategic SC partners, thus it makes sense to invest in SC integration with them. In other words, no plant operates in a closed environment, but the SC perspective is pervasive and cannot be disregarded.

Finally, our third research question aims to investigate whether the clusters affect the established relationship between SC integration and performance. Table 7 shows that the clusters (and thus the configuration of the flows at the plant level) moderate the relationship between supplier and customer integration and operational performance only to a very limited extent. Compared to Cluster 5, which turned out to be the cluster with the lowest yields from integration, Clusters 1 and 4 benefit more from supplier and customer integration in some specific performance areas:

- Cluster 1: supplier integration $\rightarrow$ cost and lead time; customer integration $\rightarrow$ quality and delivery

- Cluster 4: supplier and customer integration $\rightarrow$ cost and lead time

\section{Conclusions}

In this paper we have attempted to bridge two streams of literature, i.e. manufacturing network and supply chain management, which are seldom investigated together. Thanks to the data from the sixth edition of the International Manufacturing Strategy Survey, we have developed an empirical taxonomy, consisting of five configurations of plants, based on the extent to which they exchange products with other plants in the network in contrast to how much they exchange with external suppliers and customers.

Next, we characterized the plants belonging to different clusters by using a set of literature-based variables related to the role of the plant, finding several significant relationships. Our results therefore highlight to researchers and practitioners that the design of the product flows in a network is tightly related to the role assumed by the different plants, despite these two aspects are often treated separately. Even if not tested in this paper, and as a possible future development, we can hypothesize that networks in which the design of the flows suits the role of the plant will perform better in terms of operational performance.

However, we found no significant differences among clusters in the adoption of SC integration practices and limited moderating impact of the identified configurations on the relationship between supply chain integration and operational performance. This result highlights that the way in which the network is managed and coordinated has limited impact on how the SC is managed and the benefits that can be achieved. In other words, we found no sign of trade-off between the so called internal embeddedness (integration within the network) and external embeddedness (integration in the supply chain) (Ciabuschi et al., 2011). As a consequence, SC integration should be pushed by the headquarters and pursued by plant managers even in plants with limited external exchanges, such as Cluster 1 (Local Process Specialist).

For supply chain scholars, our results show that studies conducted at plants which are part of a network are not too much affected by the structure of the flows. Still, future research could seek for differences in how the supply chain is managed in stand-alone plants vs plants which are part of a network. For researchers in manufacturing networks, our study provides an innovative flow-based perspective that can be put in relation to 
coordination mechanisms, such as autonomy of the plant, or the level of responsibility of the plant.

Our work is still at a theory building stage (Voss et al., 2002) and our purpose was to identify the key variables, understand their mutual relationships and propose a new taxonomy of plants in manufacturing networks. Further developments of this work may, for instance, explore more in depth, maybe through case studies, the combined design and management of manufacturing network configuration and supply chain integration. 


\section{References}

Achcaoucaou, F., Miravitlles, P. and León-Darder, F. (2014), "Knowledge sharing and subsidiary R\&D mandate development: A matter of dual embeddedness", International Business Review, Vol. 23, No. 1, pp. 76-90.

Alfalla-Luque, R., Medina-Lopez, C. and Dey, P. K. (2013), "Supply chain integration framework using literature review", Production Planning \& Control, Vol. 24, No. 8-9, pp. 800-817.

Andersson, U. and Forsgren, M. (1996), "Subsidiary embeddedness and control in the multinational corporation", International business review, Vol. 5, No. 5, pp. 487-508.

Baron, R. M. and Kenny, D. A. (1986), "The moderator-mediator variable distinction in social psychological research: Conceptual, strategic, and statistical considerations", Journal of personality and social psychology, Vol. 51, No. 6, pp. 1173-1182.

Berghman, L., Matthyssens, P. and Vandenbempt, K. (2012), "Value innovation, deliberate learning mechanisms and information from supply chain partners", Industrial Marketing Management, Vol. 41, No. 1, pp. 27-39.

Birkinshaw, J., Hood, N. and Young, S. (2005), "Subsidiary entrepreneurship, internal and external competitive forces, and subsidiary performance", International Business Review, Vol. 14, No. 2, pp. 227-248.

Brennan, L., Ferdows, K., Godsell, J., Golini, R., Keegan, R., Kinkel, S., Srai, J. S. and Taylor, M. (2015), "Manufacturing in the world: where next?", International Journal of Operations \& Production Management, Vol. 35, No. 9, pp. 1253 1274.

Byrne, B. M. and Stewart, S. M. (2006), "Teacher's corner: The MACS approach to testing for multigroup invariance of a second-order structure: a walk through the process", Structural Equation Modeling: A Multidisciplinary Journal, Vol. 13, No. 2, pp. 287-321.

Caniato, F., Golini, R. and Kalchschmidt, M. (2013), "The effect of global supply chain configuration on the relationship between supply chain improvement programs and performance", International Journal of Production Economics, Vol. 143, No. 2, pp. 285-293.

Cheng, Y., Farooq, S. and Johansen, J. (2011), "Manufacturing network evolution: a manufacturing plant perspective", International Journal of Operations \& Production Management, Vol. 31, No. 12, pp. 1311-1331.

Cheng, Y., Farooq, S. and Johansen, J. (2015), "International manufacturing network: past, present, and future", International Journal of Operations \& Production Management, Vol. 35, No. 3, pp. 392-429.

Ciabuschi, F., Dellestrand, H. and Martín, O. M. (2011), "Internal embeddedness, headquarters involvement, and innovation importance in multinational enterprises", Journal of Management Studies, Vol. 48, No. 7, pp. 1612-1639.

Colotla, I., Shi, Y. and Gregory, M. J. (2003), "Operation and performance of international manufacturing networks", International Journal of Operations \& Production Management, Vol. 23, No. 10, pp. 1184-1206.

Danese, P. and Romano, P. (2011), "Supply chain integration and efficiency performance: a study on the interactions between customer and supplier integration", Supply Chain Management: An International Journal, Vol. 16, No. 4, pp. 220-230.

Danese, P., Romano, P. and Formentini, M. (2013), "The impact of supply chain integration on responsiveness: The moderating effect of using an international 
supplier network", Transportation Research Part E: Logistics and Transportation Review, Vol. 49, No. 1, pp. 125-140.

Feldmann, A. and Olhager, J. (2013), "Plant roles: Site competence bundles and their relationships with site location factors and performance", International Journal of Operations \& Production Management, Vol. 33, No. 6, pp. 722-744.

Ferdows, K. (1997), "Making the most of foreign factories", Harvard Business Review, Vol. 75, No., pp. 73-91.

Ferdows, K., Vereecke, A. and De Meyer, A. (2016), "Delayering the global production network into congruent subnetworks", Journal of Operations Management, Vol. 41, No., pp. 63-74.

Flynn, B. B., Huo, B. and Zhao, X. (2010), "The impact of supply chain integration on performance: A contingency and configuration approach", Journal of Operations Management, Vol. 28, No. 1, pp. 58-71.

Fornell, C. and Larcker, D. F. (1981), "Evaluating structural equation models with unobservable variables and measurement error", Journal of marketing research, Vol., No., pp. 39-50.

Gammelgaard, J., McDonald, F., Stephan, A., Tüselmann, H. and Dörrenbächer, C. (2012), "The impact of increases in subsidiary autonomy and network relationships on performance", International Business Review, Vol. 21, No. 6, pp. 1158-1172.

Gimenez, C., van der Vaart, T. and Pieter van Donk, D. (2012), "Supply chain integration and performance: the moderating effect of supply complexity", International Journal of Operations \& Production Management, Vol. 32, No. 5, pp. 583-610.

Golini, R., Caniato, F. and Kalchschmidt, M. (2016), "Linking global value chains and supply chain management: evidence from the electric motors industry", Production Planning \& Control, Vol. 27, No. 11, pp. 934-951.

Gupta, A. K. and Govindarajan, V. (1991), "Knowledge flows and the structure of control within multinational corporations", Academy of management review, Vol. 16, No. 4, pp. 768-792.

Gupta, A. K. and Govindarajan, V. (2000), "Knowledge flows within multinational corporations", Strategic management journal, Vol. 21, No. 4, pp. 473-496.

Hair, J. F., Anderson, R. E., Tatham, R. L. and Black, W. C. (1998), Multivariate data analysis, Prentice-Hall, Upper Saddle River, NJ.

Hanson, G. H., Mataloni Jr, R. J. and Slaughter, M. J. (2005), "Vertical production networks in multinational firms", Review of Economics and statistics, Vol. 87, No. 4, pp. 664-678.

Hayes, R. H. and Wheelwright, S. C. (1984), Restoring our competitive edge: Competing through manufacturing, John Wiley \& Sons Inc, New York.

Ketchen, D. J. and Shook, C. L. (1996), "The application of cluster analysis in strategic management research: an analysis and critique", Strategic Management Journal, Vol. 17, No. 6, pp. 441-458.

Ketokivi, M. A. and Schroeder, R. G. (2004), "Strategic, structural contingency and institutional explanations in the adoption of innovative manufacturing practices", Journal of Operations Management, Vol. 22, No. 1, pp. 63-89.

Lindberg, P., Voss, C. and Blackmon, K. L. (1998), International manufacturing strategies: context, content, and change, Kluwer Academic Pub.

Maritan, C. A., Brush, T. H. and Karnani, A. G. (2004), "Plant roles and decision autonomy in multinational plant networks", Journal of Operations Management, Vol. 22, No. 5, pp. 489-503. 
McDonald, F., Warhurst, S. and Allen, M. (2008), "Autonomy, embeddedness, and the performance of foreign owned subsidiaries", Multinational Business Review, Vol. 16, No. 3, pp. 73-92.

Meijboom, B. and Vos, B. (1997), "International manufacturing and location decisions: balancing configuration and co-ordination aspects", International Journal of Operations \& Production Management, Vol. 17, No. 8, pp. 790-805.

Meijboom, B. and Vos, B. (2004), "Site competence dynamics in international manufacturing networks: instrument development and a test in Eastern European factories", Journal of Purchasing and Supply Management, Vol. 10, No. 3, pp. 127-136.

Meyer, K. E., Mudambi, R. and Narula, R. (2011), "Multinational enterprises and local contexts: the opportunities and challenges of multiple embeddedness", Journal of Management Studies, Vol. 48, No. 2, pp. 235-252.

Monteiro, L. F., Arvidsson, N. and Birkinshaw, J., (2007). "Intra-firm knowledge flows: explaining subsidiary isolation and its performance implications", paper presented at Academy of Management Proceedings.

Najafi-Tavani, Z., Giroud, A. and Andersson, U. (2014), "The interplay of networking activities and internal knowledge actions for subsidiary influence within MNCs", Journal of World Business, Vol. 49, No. 1, pp. 122-131.

O'Donnell, S. W. (2000), "Managing foreign subsidiaries: agents of headquarters, or an interdependent network?", Strategic Management Journal, Vol. 21, No. 5, pp. 525-548.

Powell, T. C. (1995), "Total quality management as competitive advantage: a review and empirical study", Strategic Management Journal, Vol. 16, No. 1, pp. 15-37.

Rudberg, M. and Olhager, J. (2003), "Manufacturing networks and supply chains: an operations strategy perspective", Omega, Vol. 31, No. 1, pp. 29-39.

Rudberg, M. and West, B. M. (2008), "Global operations strategy: Coordinating manufacturing networks", Omega, Vol. 36, No. 1, pp. 91-106.

Sartor, M., Orzes, G., Nassimbeni, G., Jia, F. and Lamming, R. (2015), "International purchasing offices in China: roles and resource/capability requirements", International Journal of Operations \& Production Management, Vol. 35, No. 8, pp. 1125-1157.

Schmenner, R. W. (1979), "Look beyond the obvious in plant location", Harvard Business Review, Vol. 57, No. 1, pp. 126-132.

Schmenner, R. W. (1982), "Multiplant manufacturing strategies among the Fortune 500", Journal of Operations Management, Vol. 2, No. 2, pp. 77-86.

Sharma, S. (1996), Applied multivariate techniques, John Wiley \& Sons, Inc., New York.

Shi, Y. and Gregory, M. (1998), "International manufacturing networks - to develop global competitive capabilities", Journal of operations management, Vol. 16, No. 2-3, pp. 195-214.

Sousa, R. and Voss, C. A. (2001), "Quality management: universal or context dependent?", Production and Operations Management, Vol. 10, No. 4, pp. 383404.

Sousa, R. and Voss, C. A. (2008), "Contingency research in operations management practices", Journal of Operations Management, Vol. 26, No. 6, pp. 697-713.

Szulanski, G. (1996), "Exploring internal stickiness: Impediments to the transfer of best practice within the firm", Strategic Management Journal, Vol. 17, No., pp. 2743. 
Van de Vijver, F. J. R. and Leung, K. (1997), Methods and data analysis for crosscultural research, Sage Publications, Inc, Thousands Oaks, USA.

Vereecke, A. and Van Dierdonck, R. (2002), "The strategic role of the plant: testing Ferdows's model", International Journal of Operations \& Production Management, Vol. 22, No. 5/6, pp. 492-514.

Vereecke, A., Van Dierdonck, R. and De Meyer, A. (2006), "A typology of plants in global manufacturing networks", Management Science, Vol. 52, No. 11, pp. 1737-1750.

Voss, C., Tsikriktsis, N. and Frohlich, M. (2002), "Case research in operations management", International Journal of Operations \& Production Management, Vol. 22, No. 2, pp. 195-219.

Wiengarten, F., Pagell, M., Ahmed, M. U. and Gimenez, C. (2014), "Do a country's logistical capabilities moderate the external integration performance relationship?", Journal of Operations Management, Vol. 32, No. 1, pp. 51-63.

Wong, C. Y., Boon-Itt, S. and Wong, C. W. (2011), "The contingency effects of environmental uncertainty on the relationship between supply chain integration and operational performance", Journal of Operations Management, Vol. 29, No. 6, pp. 604-615.

Young, S. and Tavares, A. T. (2004), "Centralization and autonomy: back to the future", International Business Review, Vol. 13, No. 2, pp. 215-237. 


\section{Appendix}

Table A1 - Distribution of the clusters by type of network, ISIC Code, Country and Size (values are in row percentage)

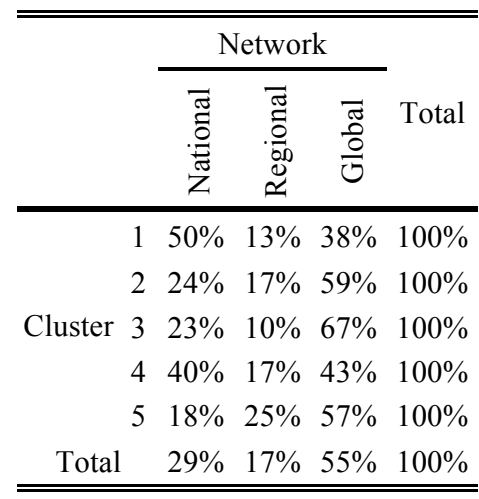

\begin{tabular}{|c|c|c|c|c|c|c|c|c|}
\hline & & \multicolumn{6}{|c|}{ ISIC Code } & \multirow[t]{2}{*}{ Total } \\
\hline & & 25 & 26 & 27 & 28 & 29 & 30 & \\
\hline \multirow{5}{*}{ Cluster } & 1 & $29 \%$ & $15 \%$ & $21 \%$ & $8 \%$ & $21 \%$ & $6 \%$ & $100 \%$ \\
\hline & 2 & $26 \%$ & $13 \%$ & $17 \%$ & $27 \%$ & $13 \%$ & $5 \%$ & $100 \%$ \\
\hline & 3 & $41 \%$ & $10 \%$ & $5 \%$ & $31 \%$ & $8 \%$ & $5 \%$ & $100 \%$ \\
\hline & 4 & $28 \%$ & $8 \%$ & $25 \%$ & $13 \%$ & $17 \%$ & $9 \%$ & $100 \%$ \\
\hline & 5 & $32 \%$ & $14 \%$ & $18 \%$ & $21 \%$ & $14 \%$ & $0 \%$ & $100 \%$ \\
\hline Total & & $29 \%$ & $12 \%$ & $17 \%$ & $23 \%$ & $14 \%$ & $5 \%$ & $100 \%$ \\
\hline
\end{tabular}

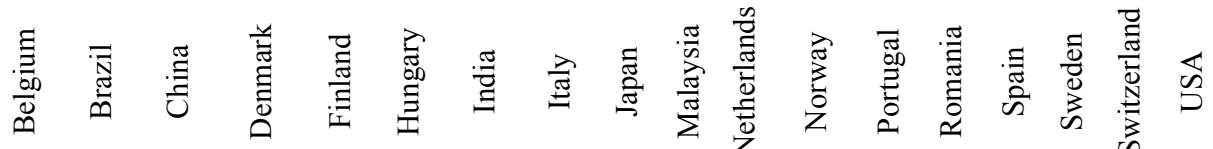

\begin{tabular}{rlccccccccccccccccccc}
\hline Cluster & 1 & $2 \%$ & $6 \%$ & $10 \%$ & $2 \%$ & $6 \%$ & $2 \%$ & $29 \%$ & $0 \%$ & $17 \%$ & $4 \%$ & $2 \%$ & $0 \%$ & $2 \%$ & $10 \%$ & $0 \%$ & $2 \%$ & $0 \%$ & $4 \%$ & $100 \%$ \\
& 2 & $6 \%$ & $7 \%$ & $14 \%$ & $4 \%$ & $4 \%$ & $7 \%$ & $2 \%$ & $6 \%$ & $8 \%$ & $3 \%$ & $8 \%$ & $6 \%$ & $8 \%$ & $2 \%$ & $3 \%$ & $6 \%$ & $5 \%$ & $5 \%$ & $100 \%$ \\
& 3 & $5 \%$ & $3 \%$ & $8 \%$ & $8 \%$ & $3 \%$ & $3 \%$ & $0 \%$ & $10 \%$ & $5 \%$ & $5 \%$ & $5 \%$ & $15 \%$ & $5 \%$ & $0 \%$ & $5 \%$ & $0 \%$ & $3 \%$ & $18 \%$ & $100 \%$ \\
& $2 \%$ & $4 \%$ & $6 \%$ & $6 \%$ & $0 \%$ & $2 \%$ & $19 \%$ & $2 \%$ & $40 \%$ & $4 \%$ & $0 \%$ & $2 \%$ & $2 \%$ & $6 \%$ & $0 \%$ & $2 \%$ & $4 \%$ & $2 \%$ & $100 \%$ \\
& 5 & $7 \%$ & $7 \%$ & $7 \%$ & $7 \%$ & $4 \%$ & $11 \%$ & $11 \%$ & $0 \%$ & $7 \%$ & $0 \%$ & $4 \%$ & $0 \%$ & $4 \%$ & $4 \%$ & $7 \%$ & $7 \%$ & $7 \%$ & $7 \%$ & $100 \%$ \\
Total & $5 \%$ & $6 \%$ & $11 \%$ & $4 \%$ & $3 \%$ & $5 \%$ & $8 \%$ & $4 \%$ & $13 \%$ & $3 \%$ & $5 \%$ & $5 \%$ & $5 \%$ & $4 \%$ & $3 \%$ & $4 \%$ & $4 \%$ & $6 \%$ & $100 \%$ \\
\hline \hline
\end{tabular}

\begin{tabular}{|c|c|c|c|c|c|}
\hline & & \multicolumn{3}{|c|}{ Size } & \multirow[t]{2}{*}{ Total } \\
\hline & & $\begin{array}{l}\overline{\overline{\varpi ् ञ}} \\
\text { क }\end{array}$ & $\begin{array}{l}\Xi \\
\text { 离 } \\
\sum\end{array}$ & $\begin{array}{l}\stackrel{8}{\infty} \\
\vec{\Xi} \\
\Xi\end{array}$ & \\
\hline \multirow{5}{*}{ Cluster } & 1 & $21 \%$ & $27 \%$ & $52 \%$ & $100 \%$ \\
\hline & 2 & $38 \%$ & $15 \%$ & $47 \%$ & $100 \%$ \\
\hline & 3 & $49 \%$ & $15 \%$ & $36 \%$ & $100 \%$ \\
\hline & 4 & $28 \%$ & $15 \%$ & $57 \%$ & $100 \%$ \\
\hline & 5 & $25 \%$ & $29 \%$ & $46 \%$ & $100 \%$ \\
\hline Total & & $34 \%$ & $18 \%$ & $48 \%$ & $100 \%$ \\
\hline
\end{tabular}


Table A2 - Role of the plant in the network - measures and scales

\begin{tabular}{|c|c|c|}
\hline Construct & Label & Measure and Scale \\
\hline \multirow[t]{2}{*}{ Market Scope } & MS1 & $\begin{array}{l}\text { Your plant serves just a specified surrounding geographic area/market (1) - Your plant } \\
\text { serves the whole world / global market (5) }\end{array}$ \\
\hline & MS2 & $\begin{array}{l}\text { Your product is tailored to the local needs (1) - The product you produce is the same for } \\
\text { all over the world (5) }\end{array}$ \\
\hline $\begin{array}{l}\text { Production } \\
\text { Scope }\end{array}$ & PS & $\begin{array}{l}\text { Your plant covers only some specific production steps (the others are performed by } \\
\text { other plants in the network) (1) - Your plant covers the full production process (5) }\end{array}$ \\
\hline \multirow[t]{2}{*}{ Control } & $\mathrm{C} 1$ & $\begin{array}{l}\text { You can make your own strategic decisions (1) - The strategy is set by another plant in } \\
\text { the network or an international division (5) }\end{array}$ \\
\hline & $\mathrm{C} 2$ & $\begin{array}{l}\text { This plant is autonomous in defining the production plan (1) - Production plans are } \\
\text { coordinated by another plant or an international division (5) }\end{array}$ \\
\hline \multirow[t]{2}{*}{ Responsibility } & R1 & No responsibility on Supply Chain (1) - Full responsibility on Supply Chain (5) \\
\hline & R2 & No responsibility on Development - Full responsibility on Development (5) \\
\hline $\begin{array}{l}\text { Low cost } \\
\text { advantage }\end{array}$ & LCA & $\begin{array}{l}\text { Your current advantage is to access to low cost resources: Strongly disagree (1) Strongly } \\
\text { Agree (5) }\end{array}$ \\
\hline $\begin{array}{l}\text { Skill and } \\
\text { knowledge } \\
\text { advantage }\end{array}$ & S\&KA & $\begin{array}{l}\text { Your current advantage is to access to knowledge and skills: - Strongly disagree (1) } \\
\text { Strongly Agree (5) }\end{array}$ \\
\hline \multirow{5}{*}{$\begin{array}{l}\text { Current level of } \\
\text { implementation } \\
\text { of } \\
\text { Manufacturing } \\
\text { network } \\
\text { integration } \\
\text { programs (MN } \\
\text { Programs) }\end{array}$} & MN1 & $\begin{array}{l}\text { Improve information sharing for the coordination of the flow of goods between your } \\
\text { plant and other plants of the network - None (1) - High (5) }\end{array}$ \\
\hline & MN2 & $\begin{array}{l}\text { Improve joint decision making to define production plans and allocate production in } \\
\text { collaboration with other plants in the network - None (1) - High (5) }\end{array}$ \\
\hline & MN3 & Improve innovation sharing / joint innovation with other plants - None (1) - High (5) \\
\hline & MN4 & $\begin{array}{l}\text { Improve the use of technology to support communication with other plants of the } \\
\text { network - None (1) - High (5) }\end{array}$ \\
\hline & MN5 & $\begin{array}{l}\text { Developing a comprehensive network performance management system - None (1) - } \\
\text { High (5) }\end{array}$ \\
\hline
\end{tabular}

Table A3 - SC management and performance items and scales

\begin{tabular}{|c|c|c|}
\hline \multirow{3}{*}{$\begin{array}{l}\text { Current level of } \\
\text { implementation of } \\
\text { Supplier Integration } \\
\text { programs (SI } \\
\text { Programs) }\end{array}$} & SI1 & Sharing information with key suppliers - None (1) - High (5) \\
\hline & SI2 & Developing collaborative approaches with key suppliers - None (1) - High (5) \\
\hline & SI3 & Joint decision making with key suppliers - None (1) - High (5) \\
\hline \multirow{3}{*}{$\begin{array}{l}\text { Current level of } \\
\text { implementation of } \\
\text { Customer Integration } \\
\text { programs (CI } \\
\text { Programs) }\end{array}$} & CI1 & Sharing information with key customers - None (1) - High (5) \\
\hline & $\mathrm{CI} 2$ & Developing collaborative approaches with key customers - None (1) - High (5) \\
\hline & $\mathrm{CI} 3$ & Joint decision making with key customers - None (1) - High (5) \\
\hline \multirow{4}{*}{$\begin{array}{l}\text { Costs and Lead Time } \\
\text { (relative to main } \\
\text { competitors) }\end{array}$} & CLT1 & Unit cost - Much Lower (1) - Much Higher (5) \\
\hline & CLT2 & Ordering costs - Much Lower (1) - Much Higher (5) \\
\hline & CLT3 & Manufacturing lead time - Much Lower (1) - Much Higher (5) \\
\hline & CLT4 & Procurement lead time - Much Lower (1) - Much Higher (5) \\
\hline \multirow{4}{*}{$\begin{array}{l}\text { Quality and Delivery } \\
\text { (relative to main } \\
\text { competitors) }\end{array}$} & QD1 & Conformance quality - Much Lower (1) - Much Higher (5) \\
\hline & QD2 & Product quality - Much Lower (1) - Much Higher (5) \\
\hline & QD3 & Delivery speed - Much Lower (1) - Much Higher (5) \\
\hline & QD4 & Delivery reliability - Much Lower (1) - Much Higher (5) \\
\hline
\end{tabular}


Table A4 - Exploratory Factor Analysis of the items related to the role of the plant in the network

\begin{tabular}{|c|c|c|c|c|c|c|c|}
\hline \multirow[b]{2}{*}{$\begin{array}{l}\text { Item (see } \\
\text { Table A2) }\end{array}$} & \multicolumn{7}{|c|}{ Component } \\
\hline & $\begin{array}{c}\mathrm{MN} \\
\text { Programs } \\
\end{array}$ & Control & $\begin{array}{c}\text { Responsibi } \\
\text { lity }\end{array}$ & $\begin{array}{l}\text { Market } \\
\text { Scope }\end{array}$ & $\begin{array}{c}\text { Production } \\
\text { Scope } \\
\end{array}$ & $\begin{array}{c}\text { Skill\&Kno } \\
\text { wledge } \\
\text { Adv. } \\
\end{array}$ & $\begin{array}{c}\text { Low cost } \\
\text { adv. }\end{array}$ \\
\hline LCA & .228 & .126 & -.069 & -.007 & -.050 & .010 & .941 \\
\hline S\&KA & .166 & -.015 & .111 & .025 & .045 & .969 & .009 \\
\hline MS1 & -.025 & -.040 & .176 & .628 & .451 & .136 & .169 \\
\hline MS2 & .112 & .126 & -.037 & .901 & -.047 & -.042 & -.088 \\
\hline R1 & .062 & -.084 & .841 & .000 & .160 & .044 & .002 \\
\hline R2 & -.028 & -.143 & .844 & .053 & .014 & .070 & -.068 \\
\hline PS & .024 & -.062 & .129 & .066 & .924 & .021 & -.075 \\
\hline $\mathrm{C} 1$ & .097 & .870 & -.164 & .040 & .090 & .001 & .002 \\
\hline C2 & .092 & .837 & -.076 & .070 & -.181 & -.018 & .132 \\
\hline MN1 & .824 & .050 & .019 & .101 & -.030 & .007 & .108 \\
\hline MN2 & .775 & .109 & -.055 & .027 & -.080 & .072 & .081 \\
\hline MN3 & .794 & .016 & .039 & .007 & -.010 & .163 & .050 \\
\hline MN4 & .803 & .059 & .042 & .019 & .124 & -.046 & .065 \\
\hline MN5 & .808 & .036 & -.003 & -.006 & .020 & .051 & .015 \\
\hline \multicolumn{8}{|c|}{$\begin{array}{l}\text { Varimax Rotation } \\
\text { Variance Explained: } 77 \% \\
\text { KMO: } 0.778 \\
\text { Bartlett's Test of Sphericity }\end{array}$} \\
\hline
\end{tabular}


Table 1 - Distribution of the sample by country, industry and size

\begin{tabular}{|c|c|c|c|c|c|}
\hline Country & Frequency & Percentage & ISIC Code & Frequency & Percentage \\
\hline Belgium & 17 & 5 & 25 & 104 & 29 \\
\hline Brazil & 21 & 6 & 26 & 44 & 12 \\
\hline China & 40 & 11 & 27 & 63 & 17 \\
\hline Denmark & 16 & 4 & 28 & 82 & 23 \\
\hline Finland & 12 & 3 & 29 & 52 & 14 \\
\hline Hungary & 20 & 5 & 30 & 19 & 5 \\
\hline India & 30 & 8 & Total & 364 & 100 \\
\hline Italy & 16 & 4 & & & \\
\hline Japan & 48 & 13 & Employees & Frequency & Percentage \\
\hline Malaysia & 11 & 3 & Small (50-250) & 125 & 34 \\
\hline Netherlands & 20 & 5 & Medium (250-500) & 65 & 18 \\
\hline Norway & 19 & 5 & Large $(500+)$ & 174 & 48 \\
\hline Portugal & 20 & 5 & Total & 364 & 100 \\
\hline Romania & 13 & 4 & \multirow{6}{*}{\multicolumn{3}{|c|}{$\begin{array}{l}\text { ISIC Rev. } 4 \text { Code } \\
\text { 25: Manufacture of fabricated metal products, except } \\
\text { machinery and equipment; 26: Manufacture of computer, } \\
\text { electronic and optical products; 27: Manufacture of } \\
\text { electrical equipment; 28: Manufacture of machinery and } \\
\text { equipment not elsewhere classified; 29: Manufacture of } \\
\text { motor vehicles, trailers and semi-trailers; 30: Manufacture } \\
\text { of other transport equipment }\end{array}$}} \\
\hline Spain & 10 & 3 & & & \\
\hline Sweden & 15 & 4 & & & \\
\hline Switzerland & 14 & 4 & & & \\
\hline USA & 22 & 6 & & & \\
\hline Total & 364 & 100 & & & \\
\hline
\end{tabular}

Table 2 - Average values and number of cases per cluster

\begin{tabular}{cccc}
\hline & $\begin{array}{c}\text { Horizontal } \\
\text { Inflows }\end{array}$ & $\begin{array}{c}\text { Horizontal } \\
\text { Outflows }\end{array}$ & Number of cases \\
\hline 1 & 81.46 & 85.79 & 48 \\
2 & 11.86 & 9.26 & 196 \\
3 & 74.95 & 15.05 & 39 \\
4 & 49.06 & 52.21 & 53 \\
5 & 13.04 & 82.86 & 28 \\
\hline Total & $\mathbf{3 3 . 3 0}$ & $\mathbf{3 1 . 8 9}$ & $\mathbf{3 6 4}$ \\
\hline
\end{tabular}


Table 3 - Results of the confirmatory factor analysis

\begin{tabular}{|c|c|c|c|c|c|c|}
\hline & & & Estimate & $P$ & $\mathrm{CR}$ & AVE \\
\hline $\mathrm{C} 1$ & $<---$ & Control & 1.000 & & .69 & .73 \\
\hline G2 & $<---$ & Control & .797 & .000 & & \\
\hline $\mathrm{R} 1$ & $<---$ & Responsibility & 1.000 & & .66 & .70 \\
\hline $\mathrm{R} 2$ & $<---$ & Responsibility & 1.114 & .000 & & \\
\hline MN1 & $<---$ & MN Programs & 1.000 & & .87 & .75 \\
\hline MN2 & $<---$ & MN Programs & .988 & .000 & & \\
\hline MN3 & $<---$ & MN Programs & .987 & .000 & & \\
\hline MN4 & $<---$ & MN Programs & .984 & .000 & & \\
\hline MN5 & $<---$ & MN Programs & 1.090 & .000 & & \\
\hline CLT1 & $<---$ & Cost\&Lead Time & 1.000 & & .75 & .66 \\
\hline CLT2 & $<---$ & Cost\&Lead Time & .832 & .000 & & \\
\hline CLT3 & $<---$ & Cost\&Lead Time & 1.078 & .000 & & \\
\hline CLT4 & $<---$ & Cost\&Lead Time & .865 & .000 & & \\
\hline QD1 & $<---$ & Quality\&Delivery & 1.000 & & .79 & .70 \\
\hline QD2 & $<---$ & Quality\&Delivery & 1.052 & .000 & & \\
\hline QD3 & $<---$ & Quality\&Delivery & 1.511 & .000 & & \\
\hline QD4 & $<---$ & Quality\&Delivery & 1.779 & .000 & & \\
\hline SI1 & $<---$ & SI Programs & 1.000 & & .84 & .80 \\
\hline SI2 & $<---$ & SI Programs & 1.119 & .000 & & \\
\hline SI3 & $<---$ & SI Programs & 1.083 & .000 & & \\
\hline CI1 & $<---$ & CI Programs & 1.000 & & .87 & .83 \\
\hline $\mathrm{CI} 2$ & $<---$ & CI Programs & 1.047 & .000 & & \\
\hline $\mathrm{CI} 3$ & $<---$ & CI Programs & 1.027 & .000 & & \\
\hline
\end{tabular}

Table 4-Discriminant validity test

\begin{tabular}{lccccccc}
\hline & 1 & 2 & 3 & 4 & 5 & 6 & 7 \\
\hline Control (1) & $\mathbf{0 . 7 2 8}$ & -0.361 & 0.222 & 0.148 & -0.083 & 0.070 & 0.159 \\
Responsibility (2) & -0.361 & $\mathbf{0 . 7 0 2}$ & 0.051 & 0.099 & 0.178 & 0.240 & 0.079 \\
MN Programs (3) & 0.222 & 0.051 & $\mathbf{0 . 7 5 2}$ & 0.376 & 0.417 & 0.638 & 0.682 \\
Cost\&Lead Time (4) & 0.148 & 0.099 & 0.376 & $\mathbf{0 . 6 5 5}$ & 0.404 & 0.346 & 0.238 \\
Quality\&Delivery (5) & -0.083 & 0.178 & 0.417 & 0.404 & $\mathbf{0 . 6 9 9}$ & 0.379 & 0.376 \\
SI Programs (6) & 0.070 & 0.240 & 0.638 & 0.346 & 0.379 & $\mathbf{0 . 7 9 8}$ & 0.724 \\
CI Programs (7) & 0.159 & 0.079 & 0.682 & 0.238 & 0.376 & 0.724 & $\mathbf{0 . 8 3 4}$ \\
\hline
\end{tabular}


Table 5 - Results of the first MANOVA analysis. Values in bold indicate the maximum and values in italic the minimum for each variable. In brackets are reported the clusters that are significantly different at sig 0.05 (LSD test).

\begin{tabular}{|c|c|c|c|c|c|c|c|c|}
\hline & & & & Cluste & average & values & & \\
\hline $\begin{array}{l}\text { Plant role } \\
\text { variables }\end{array}$ & $\begin{array}{l}\text { MANOVA } \\
\text { Sig. }\end{array}$ & $\begin{array}{l}\text { Levene } \\
\text { Homog. } \\
\text { test }\end{array}$ & $3 \frac{1}{5}$ & $3^{3} 1$ & $3 \frac{1}{2}$ & 3 & $\frac{3}{4} 5$ & Sample average \\
\hline Market Scope & $.399^{1}$ & .011 & 3.30 & 3.29 & 3.08 & 3.50 & 3.61 & 3.32 \\
\hline $\begin{array}{l}\text { Production } \\
\text { Scope }\end{array}$ & .022 & .138 & $\begin{array}{l}3.44 \\
(2 ; 3)\end{array}$ & $\begin{array}{c}4.04 \\
(1)\end{array}$ & $\begin{array}{c}3.62 \\
(2)\end{array}$ & 3.83 & 3.61 & 3.85 \\
\hline Control & $.004^{2}$ & .003 & $\begin{array}{l}3.00 \\
(2)\end{array}$ & $\begin{array}{c}2.53 \\
(1 ; 3 ; 4) \\
\end{array}$ & $\begin{array}{c}3.09 \\
(2)\end{array}$ & $\begin{array}{c}3.03 \\
(2) \\
\end{array}$ & 2.91 & 2.75 \\
\hline Responsibility & .253 & .298 & 3.70 & 3.96 & 3.72 & 3.75 & 3.68 & 3.85 \\
\hline $\begin{array}{l}\text { Low cost } \\
\text { advantage }\end{array}$ & .028 & .228 & 3.04 & $\begin{array}{c}2.74 \\
(4)\end{array}$ & $\begin{array}{c}2.64 \\
(4)\end{array}$ & $\begin{array}{c}3.40 \\
(2 ; 3 ; 5)\end{array}$ & $\begin{array}{l}2.61 \\
(4)\end{array}$ & 2.86 \\
\hline $\begin{array}{l}\text { Skill and } \\
\text { knowledge } \\
\text { advantage }\end{array}$ & .690 & .600 & 3.54 & 3.64 & 3.51 & 3.70 & 3.86 & 3.64 \\
\hline $\begin{array}{l}\text { Manufacturing } \\
\text { Network } \\
\text { Integration }\end{array}$ & .024 & .626 & 3.32 & $\begin{array}{l}3.15 \\
(4)\end{array}$ & $\begin{array}{c}3.23 \\
(4)\end{array}$ & $\begin{array}{c}\mathbf{3 . 6 2} \\
(2 ; 3 ; 5)\end{array}$ & $\begin{array}{c}3.19 \\
(4)\end{array}$ & 3.25 \\
\hline
\end{tabular}

Table 6 - Results of the second MANOVA analysis. Values in bold indicate the maximum and values in italic the minimum for each variable. In brackets are reported the clusters that are significantly different at sig 0.05 (LSD test).

\begin{tabular}{|c|c|c|c|c|c|c|c|c|}
\hline & & & \multicolumn{5}{|c|}{ Cluster } & \multirow[b]{2}{*}{$\begin{array}{l}\text { Sample } \\
\text { average }\end{array}$} \\
\hline $\begin{array}{l}\mathrm{SC} \text { integration } \\
\text { variables }\end{array}$ & $\begin{array}{l}\text { MANOVA } \\
\text { Sig. }\end{array}$ & $\begin{array}{l}\text { Levene } \\
\text { Homog. }\end{array}$ & 34 & 2 & & & $\frac{3}{4}$ & \\
\hline SI Programs & .526 & .308 & 3.21 & 3.29 & 3.06 & 3.26 & 3.06 & 3.23 \\
\hline CI Programs & .299 & .239 & 3.26 & 3.05 & 2.93 & 3.34 & 2.80 & 3.09 \\
\hline
\end{tabular}


Table 6-Results of the regression model without clusters

\begin{tabular}{|c|c|c|c|c|c|c|c|c|}
\hline \multirow[b]{2}{*}{ Parameter } & \multicolumn{4}{|c|}{ Cost and Lead Time } & \multicolumn{4}{|c|}{ Quality and Delivery } \\
\hline & $\mathrm{B}$ & Sig. & $\mathrm{B}$ & Sig. & $\mathrm{B}$ & Sig. & $\mathrm{B}$ & Sig. \\
\hline GNI_2013 & .024 & .649 & .030 & .580 & .008 & .877 & .005 & .930 \\
\hline Size $(\ln )$ & .074 & .183 & .059 & .301 & -.082 & .138 & -.082 & .133 \\
\hline Global Network & -.044 & .429 & -.025 & .659 & -.010 & .849 & .012 & .820 \\
\hline Supplier Integration (Z) & $.282 * * *$ & .000 & & & $.310 * * *$ & .000 & & \\
\hline Customer Integration (Z) & & & $.202 * * *$ & .000 & & & $.313 * * *$ & .000 \\
\hline$R^{2}$ & .079 & & .042 & & .113 & & .114 & \\
\hline
\end{tabular}

Table 7 -Results of the regression models with clusters (baseline cluster is number 5)

\begin{tabular}{|c|c|c|c|c|c|c|c|c|c|}
\hline & Cost and & Lead & Time & & Quality ar & Id Del & ery & & \\
\hline Parameter & $\mathrm{B}$ & Sig. & $\mathrm{B}$ & Sig. & $\mathrm{B}$ & Sig. & $\mathrm{B}$ & Sig. & \\
\hline Intercept & 2.971 & .000 & 2.948 & .000 & 3.427 & .000 & 3.421 & .000 & \\
\hline Cluster 1 & -.061 & .646 & -.097 & .478 & .223 & .132 & .141 & .341 & \\
\hline Cluster 2 & .112 & .321 & .127 & .273 & .166 & .184 & .174 & .165 & \\
\hline Cluster 3 & .169 & .227 & .156 & .274 & -.005 & .973 & -.016 & .920 & \\
\hline Cluster 4 & .208 & .110 & .159 & .241 & .226 & .118 & .175 & .234 & \\
\hline GNI_2013 & $1.2 \mathrm{E}-06$ & .285 & $9.8 \mathrm{E}-07$ & .419 & $-1.3 \mathrm{E}-06$ & .326 & $-1.3 \mathrm{E}-06$ & .311 & \\
\hline $\operatorname{Size}(\ln )$ & .008 & .628 & .012 & .494 & .002 & .911 & .002 & .930 & \\
\hline Global_Network & -.068 & .335 & -.054 & .446 & -.005 & .950 & .019 & .802 & \\
\hline Supplier Integration $(\mathrm{Z})$ & -.018 & .868 & & & .135 & .250 & & & \\
\hline Cluster $1 *$ Suppl. Int. (Z) & .228 & .072 & $*$ & & .220 & .117 & & & \\
\hline Cluster $2 *$ Suppl. Int. (Z) & .170 & .135 & & & .032 & .799 & & & \\
\hline Cluster $3 *$ Suppl. Int. (Z) & .128 & .368 & & & .011 & .943 & & & \\
\hline Cluster $4 *$ Suppl. Int. (Z) & .252 & .052 & $*$ & & .035 & .807 & & & \\
\hline Customer Integration (Z) & & & -.008 & .925 & & & .126 & .182 & \\
\hline Cluster $1 *$ Cust. Int. (Z) & & & .184 & .109 & & & .292 & .020 & $* *$ \\
\hline Cluster $2 *$ Cust. Int. (Z) & & & .124 & .196 & & & .026 & .806 & \\
\hline Cluster $3 *$ Cust. Int. (Z) & & & .027 & .838 & & & .045 & .751 & \\
\hline Cluster $4 *$ Cust. Int. (Z) & & & .246 & .053 & $*$ & & .086 & .533 & \\
\hline$*$ sig. $<.10 ; * *$ sig. $<.05$ & & & & & & & & & \\
\hline
\end{tabular}


Figure 1 - Horizontal and vertical inflows and outflows of goods from one plant

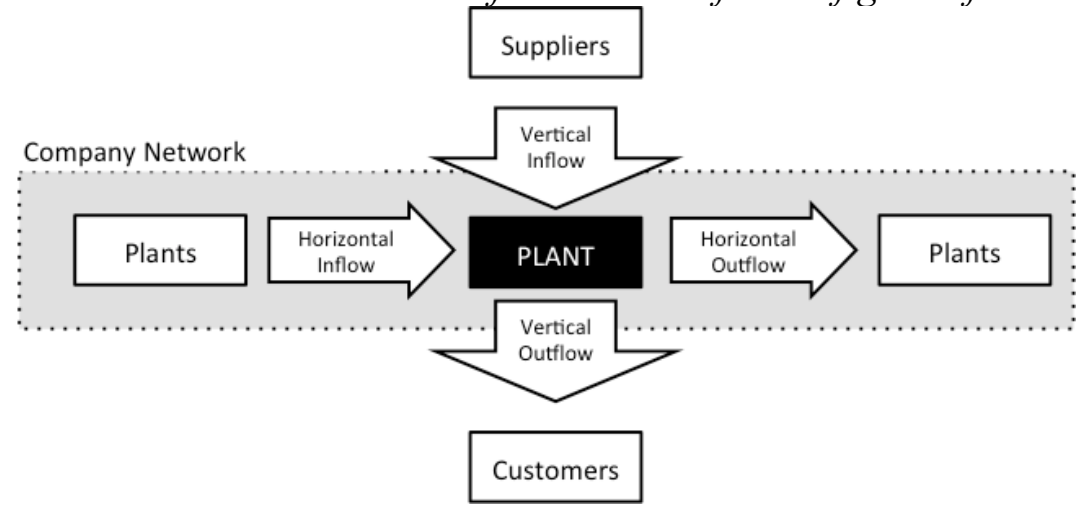

Figure 2 - The research framework

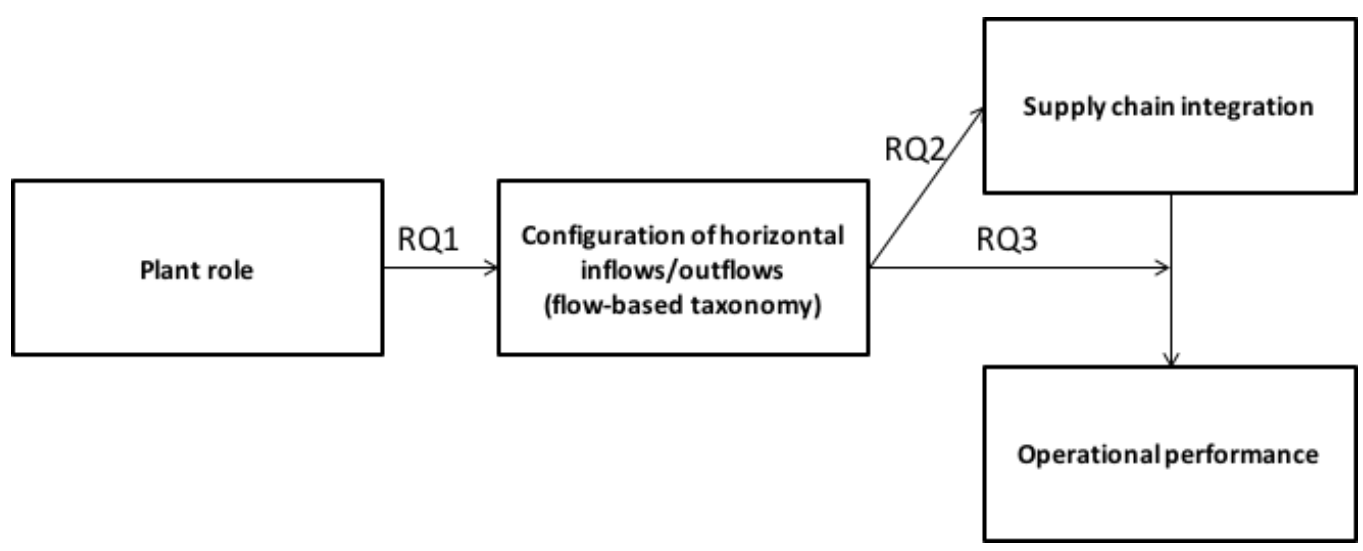


Figure 3 -Results of the cluster analysis

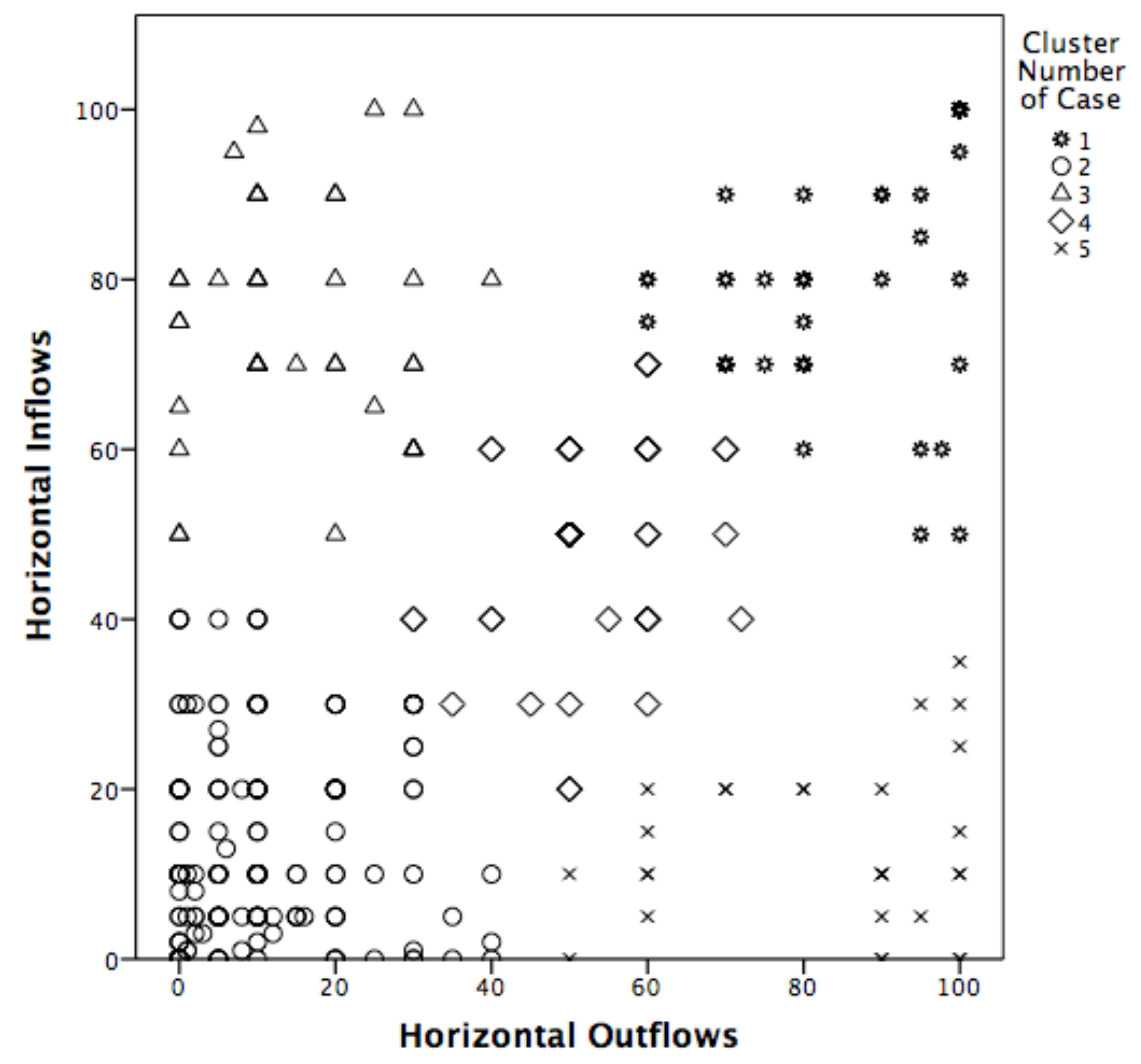

